DOI https://doi.org/10.36059/978-966-397-237-4-2

Панкратова В. О.,

кандидат юридичних наук,

старший викладач кафедри фундаментальної юриспруденції

та конституційного права

Навчально-наукового інституту права

Сумського державного університету,

м. Суми

\title{
ЛОКАЛЬНА ДЕМОКРАТІЯ: ТЕОРЕТИКО-ПРАВОВА ХАРАКТЕРИСТИКА
}

Анотація. У роботі визначено, що провідне місце в демократичних перетвореннях належить локальній демократії, оскільки ефективна система місцевого самоврядування неможлива без працюючих механізмів реалізації законодавчих норм у сфері розвитку локальної демократії як на загальнодержавному, так і на місцевому рівнях.

Визначено, що зміст терміна «локальна демократія» включає в себе досить широке коло явищ і процесів. При визначенні даного терміна в науковій доктрині робиться акцент на певному явищі або процесі. Зокрема, локальну демократію розуміють як національну модель демократії, як участь громадян в управлінні, як форму самоорганізації громадян та як демократичний устрій на муніципальному рівні.

Резюмовано, що метою локальної демократії $\epsilon$ розвиток народовладдя, широке залучення місцевих жителів до участі та вирішення питань місцевого значення. Вказано, що ефективна локальна демократія $\epsilon$ необхідною умовою для забезпечення стійкого і справедливого економічного і соціального розвитку, просування належного управління $і$ заохочення демократичних цінностей.

Визначено, що значення локальної демократії полягає в можливості ширшої участі населення у вирішенні питань місцевого значення, що зумовлює підвищення рівня правової культури. Проаналізовано міжнародно-правові акти, які врегульовують питання локальної демократії, визначено їх значення для розвитку та вдосконалення українського законодавства. 


\section{Вступ}

Важливе місце в демократичних перетвореннях належить локальній демократії, оскільки розвиток ефективної системи місцевого самоврядування та формування громадянського суспільства неможливе без створення належних нормативних та організаційних умов, а головне - працюючих механізмів реалізації законодавчих норм у сфері розвитку локальної демократії на загальнодержавному та місцевому рівнях.

Наразі роль локальної демократії постійно зростає, їі важливість та необхідність $\epsilon$ визначальною як для сталих демократичних країн, так і для країн, які стають на шлях демократичних перетворень. $\mathrm{y}$ демократичних державах з'являються нові проблеми, які пов'язані із впливом глобалізації, урбанізації, високим рівнем міграції населення, що призводить до перегляду питання про те, як самі міста можуть вирішити ці проблеми найбільш ефективно.

У країнах, в яких відбуваються демократичні перетворення, $\epsilon$ можливість створити систему локальної демократії із самих азів, спираючись на позитивний досвід зарубіжних країн, зокрема шляхом децентралізації та поліпшення місцевого самоврядування. Зокрема, в Резолюції 91 (2000) Конгресу місцевих і регіональних влад Ради Європи «Про обов'язки громадян та участі у суспільному житті», визначено, що дієва демократія на місцевому рівні - запорука життєздатної демократії на державному рівні» [27].

Сучасні виклики, пов'язані з пандемією Covid-19, стрімким розвитком інформаційної сфери, новітніх технологій тощо зумовлюють потребу міст в інноваційних методах демократичного врядування. Саме локальна демократія $\epsilon$ важливим інструментом для оперативного та ефективного вирішення проблем, які виникають на місцях.

В Україні у результаті проведення реформи децентралізації влади запроваджуються нові стандарти взаємодії органів публічної влади 3 громадою та нові підходи у реалізації повноважень місцевого самоврядування, більш демократичні та відкриті. Зокрема, все активніше застосовуються інструменти локальної демократії, такі як: звернення громадян, електронна петиція, доступ до засідань, загальні збори, консультативнодорадчі органи, контрольно-наглядові органи, бюджет участі, органи самоорганізації населення, місцеві ініціативи, громадські слухання. 
Але наразі в Україні існує ряд проблематичних питань щодо використання інструментів локальної демократії, зумовлених відсутністю належного правового регулювання зазначених інструментів, недостатньою обізнаністю громадян щодо використання цих інструментів для вирішення проблем місцевого значення тощо.

Проблематика локальної демократії досить широко висвітлена у працях зарубіжних науковців. Зокрема, дана тематика була в полі зору таких науковців, як: Д. Бернс, М. Бондар, Дж. Брукс, Г. Гаврилов, В. Гельман, Ж. Марку, С. Крамаренко, Н. Наумов, О. Новосьолова, В. Рейсінгер, Д. Райбот, К. Стоун, І. Халій, Г. Шовш та інших.

у вітчизняній доктрині питанням локальної демократії приділяється увага, зокрема у світлі вивчення та аналізу місцевого самоврядування. Серед авторів заслуговують на увагу праці М. Баймуратова, А. Батанова, С. Були, О. Буріна, В. Гнатюка, В. Кампо, Н. Латигіної, М. Лендьєл, М. Ладиби, А. Крупника, Г. Музиченко, Н. Мішиної, . Орловського, Є. Садикової, М. Цумараєва. Проте, незважаючи на наявні наукові розробки, залишається актуальним питання детального аналізу локальної демократії, що зумовлено необхідністю теоретико-правового визначення понять, умов та факторів, які визначають зміст та сутність цієї категорії.

\section{1. Теоретичні підходи до визначення поняття та особливостей локальної демократії}

Слід вказати, що значимість локальної демократії зумовлюється саме ії̈ сутністю та роллю. Адже локальний рівень найбільш наближений до населення, його потреб та проблем. Тому вирішення всіх питань місцевого значення, створення належних умов для життя доцільно забезпечити саме на місцевому рівні. Адже це можливо буде зробити оперативно та безпосередньо. I лише, якщо виникають труднощі, перепони - вирішити питання вже на державному рівні.

Вважаємо, що влучною $€$ точка зору М.С. Бондара, який наголошує на важливості місцевого самоврядування та загострює наукову увагу на декількох моментах. По-перше, питання місцевого самоврядування, пов'язані 3 необхідністю рішення повсякденних проблем населення за місцем проживання, менше всього схильні до політичних i партійних пристрастей, ідеологічних спотворень. На цьому рівні, у межах конкретного 
міста або району, села або селища, люди дістають можливість реальної участі у вирішенні питань господарсько-економічного, політичного життя, тут вони можуть безпомилково оцінити за діловими якостями своїх керівників. По-друге, на рівні місцевого самоврядування яскраво і одночасно результативно виявляються особові моменти розвитку демократичних процесів, тут проявляється «олюднений» образ соціально-економічних і політичних реформ. Саме місцеве самоврядування, що забезпечує розвиток демократії «малих просторів», здатне створити органічне поєднання влади і свободи, зовнішнього управління i внутрішньої самоорганізації населення [14, с. 17].

Дійсно, для сучасної демократичної держави важливим та визначальним фактором є раціональна та ефективна організація влади, і не лише центральної, а й місцевої, представленої системою органів місцевого самоврядування. Адже місцеве самоврядування $\epsilon$ матеріальною основою становлення і розвитку інститутів локальної демократії. Тому в даному аспекті актуальним $\epsilon$ питання про співвідношення демократії та місцевого самоврядування.

Зазначимо, що точки зору науковців у даному питанні не мають спільності та мають декілька підходів. По-перше, самоврядування це традиційний інститут, який не узгоджується 3 основними принципами демократії. По-друге, основи демократії, як влада більшості, не можуть бути застосовані до самоврядування як явища обмеженого, вузьконаправленого. I, по-третє, демократія і місцеве самоврядування нерозривно пов'язані і взаємодіють [18, с. 4-6].

А.Е. Тюлегенов вважає, що поняття самоврядування близьке, але не тотожно поняттю демократії. Демократія як спосіб здійснення політичної влади реалізується, зокрема, через систему самоврядування, і демократичність політичного режиму багато в чому визначається широтою і глибиною впровадження в практику засад самоврядування. Тому конкретні інститути самоврядування співпадають з інститутами демократії. У зв'язку із цим науковець розглядає локальну демократію в якості загального принципу конституційного ладу та найважливішого аспекту реалізації права громадян на здійснення місцевого самоврядування [31, с. 690].

Ю.М. Лермонтов на підтримку точки зору про взаємозв'язок демократії та місцевого самоврядування наводить два аргументи. По-перше, демократія та самоврядування $\epsilon$ взаємозв'язаними формами здійснення публічної влади, причому демократія $\epsilon$ 
формою здійснення державної влади, а самоврядування громадської. По-друге, загальними для демократії і самоврядування $є$ принципи свободи і рівності, народного суверенітету, виборності осіб для здійснення функції управління [20, с. 212].

С.П. Була вважає, що місцеве самоврядування та локальна демократія $є$ близькими, але все-таки відмінними поняттями. Локальна демократія $\epsilon$ тим середовищем, де діє місцеве самоврядування, що, за своєю суттю, $є$ організацією влади територіальної громади. Спільним для обох понять $\epsilon$ публічний інтерес, який вони реалізовують, а також принципи його розбудови й реалізації: солідарність, субсидіарність. Відмінність полягає в тому, що локальна демократія орієнтована на консенсус у громаді, а місцеве самоврядування - на реалізацію державного інтересу [15, с. 16$]$.

С.В. Крамаренко зазначає, що публічно-владні риси місцевого самоврядування доповнюються і збагачуються муніципальними правами і обов'язками громадян, уповноважених до автономної публічної самоорганізації в тих правових формах і тими засобами, які узгоджуються з демократичними принципами і цінностями народу і найбільшою мірою відповідають цілям вирішення питань місцевого значення. Як бачимо, в даній точці зору простежується взаємозв'язок між місцевим самоврядуванням та демократією [19, с. 21].

Приєднуємось також до даного висновку, але зауважимо, що місцеве самоврядування - це не лише форма самоорганізації, але одночасно й елемент організації публічної влади. Тому, діючи в режимі демократичної державності, демократія на місцях трансформується в локальну демократію, яка здійснюється через інститути місцевого самоврядування. При цьому як демократія, так і місцеве самоврядування - це різновиди народовладдя, тому передбачають участь громадян в обговоренні й ухваленні рішень 3 питань місцевого значення. А отже мають спільну мету широку та ефективну участь громадян в управлінні.

Зміст терміна «локальна демократія» включає в себе досить широке коло явищ і процесів. Тому різні автори при визначенні даного терміна, як правило, роблять акцент на якомусь певному явищі або процесі. Так, локальну демократію розуміють як національну модель демократії, як участь громадян в управлінні, як форму самоорганізації громадян та як демократичний устрій на муніципальному рівні. 
Як зазначає 0.0. Новоселов, локальна демократія знаходить свої витоки на початку 60-х років XX століття, що пов'язано з потребою в підвищенні ефективності функціонування органів місцевого самоврядування в США та в Західній Європі [26, с. 1]. Але наукове обгрунтування концепція локальної демократії отримала лише наприкінці XX століття, переважно в працях представників політологічних та соціальних наук.

Незважаючи на все більше поширення концепції місцевої демократії, у вітчизняній юридичній науці відсутнє не лише досить глибоке осмислення концепції, але й єдність у термінологічному підході. Зокрема, досить часто поняття «локальна демократія» ототожнюють із поняттями «місцеве самоврядування», «територіальна самоорганізація» тощо.

Термін «локальна демократія» походить від англійського терміну «local democracy» та в перекладі може мати значення «локальна, місцева або муніципальна демократія». Дана диференціація, на наш погляд, зумовлена різним перекладом терміна.

Також визначальною рисою української традиції цих досліджень $\epsilon$ переважання політико-правового підходу та історичних розвідок. Помітний брак робіт, у яких розглядається саме застосування концепції локальної демократії в політико-правовій практиці [16].

Оскільки теоретичні розвідки локальної демократії знаходять свої витоки з США та країн Західної Європи, вважаємо за доцільне в першу чергу проаналізувати наукові здобутки саме зарубіжних авторів.

Так, американський дослідник К. Стоун у праці «Режимна політика: правління в Атланті, 1946-1988» розробив теорію міських політичних режимів, в основі якої лежить ідея коаліційної природи міської влади, яка грунтується на постійній взаємодії суб'єктів публічної влади, бізнесу та громадянського суспільства [40, p. 17]. Також К. Стоун використав термін «локальний режим», під яким розумів неформальні рамки, у яких для прийняття політичних рішень співпрацюють місцеві органи влади та приватні структури. При цьому режим включає широке трактування коаліцій: не тільки виборчих, але й на основі неформальних зв'язків на різних рівнях.

Як вже було зазначено вище, перші роботи з теоретичного аналізу локальної демократії датуються кінцем XX ст. У той час локальну демократію визначали як простір для впровадження демократичних зразків поведінки; вже тоді активно залучали механізми представницької демократії - обрання локальних лідерів. 
Доцільно навести точку зору британського науковця Д. Бернса, який зазначає, що ідея локальної демократії достатньо проста - чим активніше громадяни беруть участь у прийнятті рішень на місцевому рівні, при цьому контролюючи діяльність органів місцевого самоврядування, тим більш ефективніше та демократичніше буде й сама місцева влада [34, p. 963].

Варто звернути увагу на перший глобальний звіт із децентралізації та локальній демократії, який підготувала Світова організація «Об’єднані міста та органи місцевого самоврядування» (UCLG) ще в 2008 році. У даній доповіді звертається увага на поняття «локальна демократія» та вказується, що саме дана дефініція значно варіюється від однієї країни і континенту до іншого, а разом із ним варіюється і концепція відносин між місцевим населенням і державою. Для кращого розуміння сутності локальної демократії, аналізуються суміжні 3 нею поняття децентралізація та місцеве самоврядування. У Доповіді зазначається, що локальна демократія належить до відносин між різними рівнями влади; децентралізація - до статусу місцевої влади, а місцеве самоврядування $є$ способом здійснення влади. Порівняння між трьома термінами показує конвергенцію на рівні політичних ідей та правових понять. Тому локальна демократія $\epsilon$ способом реалізації влади на місцевому рівні [36, р. 310].

Широке визначення локальної демократії надають угорські дослідники Г. Шовша i В. Зентаї, які під даною категорією розуміють тип автономного, ефективного, відкритого і представницького самоврядування, яке функціонує в середовищі громадянського суспільства та гарантованих для громадян політичних прав [39, р. 38].

За визначенням міжурядової організації International Institute for Democracy and Electoral Assistance (IDEA), локальна демократія - це самоврядування міст, селищ, сіл і районів згідно 3 демократичними принципами, як правило, шляхом обрання мерів, радників і інших посадовців на місцевому рівні [37].

Європейська асоціація локальної демократії (ALDA) дає таке тлумачення: локальна демократія - це самоврядування, що надає право місцевій владі в рамках закону регулювати i управляти частиною державних справ. Це право присуджується радам або зборам, що складаються з вільно обраних членів таємним голосуванням і підзвітних їх власному місцевому виборчому округу [38]. 
У Методичному посібнику «Локальна демократія» під редакцією Г.В. Голосова визначено, що поняття «локальна демократія» тісно пов'язано з поняттям місцевої громади, яке трактується у двох аспектах. Перший аспект визначає місцеву громаду як об'єднання людей, що проживають на території муніципального утворення. Другий - як локальну сукупність людей, об'єднаних певним інтересом. Тому, по суті, місцева громада в першому аспекті складається з спільноти у другому.

Із точки зору 0.0. Новосьолова, у формулюванні терміну «локальна демократія» потрібно враховувати широке коло явищ та процесів, яке властиве даному поняттю. Науковець надає власне визначення, дозволяє уникнути вузького трактування даного явища та надає можливість конкретного розгляду окремих його компонентів та процесів. Зокрема, він визначає місцеву демократію як систему, що динамічно розвивається з безліччю взаємопов'язаних і постійно мінливих компонентів, у рамках якої відбуваються процеси взаємодії на локальному рівні таких факторів, як наднаціональні сили та інститути, національні та місцеві уряди, громадянське суспільство, неурядові організації, а також різні групи тиску в процесі вироблення загальнозначимих рішень. Вважаємо, що дійсно дане визначення $\epsilon$ широкою трактовкою локальної демократії, оскільки поєднує в собі політико-правові особливості та компоненти локальної демократії [26, с. 12].

Ще один російський автор М.С. Бондар надає досить об'ємне визначення локальної демократії та визначає її як засновану на єдності свободи і відповідальності самоврядну форму здійснення населенням за місцем проживання публічної влади, колективних та індивідуальних прав громадян за самостійним рішенням у межах встановлених Конституцією та чинним законодавством питань місцевого значення, при безпосередньому забезпеченні життєдіяльності та наданні муніципальних послуг в інтересах місцевої громади та окремих громадян [14, с. 42].

Отже, резюмуючи підходи зарубіжних авторів, можна зробити висновок, що локальна демократія $\epsilon$ основою функціонування місцевого самоврядування, яка спирається на демократичні цінності, використовує демократичні механізми та грунтується на активній позиції місцевого населення.

Не можна обійти увагою напрацювання вітчизняних науковців у даному аспекті. Зокрема, важливий вклад у розкриття сутності локальної демократії був зроблений такими науковцями, як: 
Баймуратов М.О., Батанов О.В., Була С.П., Ващук-Огданська О.Л., Лендьєл М.О., Лациба М.В., Лукеря І.М., Музиченко Г.В., Садикова Є.О., Цумарєв М.I. та іншими ученими.

Як вже зазначалося в українській доктрині термін «локальна демократія» використовується на рівні $з$ термінами «місцева демократія» та «муніципальна демократія» як синонімічні поняття. Вважаємо, що відсутність єдності у термінології зумовлена не змістовною розбіжністю, а різницею в перекладі.

О.В. Батанов, визначаючи сутність муніципалізму, наголошує на важливості локального рівня. Зокрема, науковець вважає, що в тій державі, в якій створено й апробовано систему ефективного місцевого самоврядування та задіяно принципи муніципальної політики, може сформуватися алгоритм, згідно з яким законодавча влада обирається демократично, а виконавча влада їй підконтрольна та відповідальна. У державі, в якій сформувались інститути муніципалізму, люди обирають та контролюють як тих, хто приймає національні закони за якими вони будуть жити, так і тих, хто ці закони здійснює на місцях [13, с. 25].

М.О. Лендьєл у монографічному дослідженні використовує термін «місцева демократія», під якою розуміє політичний режим, який реалізується на найнижчому територіальному рівні публічної влади в межах інститутів місцевого самоврядування, гарантується державою i характерними ознаками якого $\epsilon$ автономія, поєднання представницької й безпосередньої форм демократії, конкуренція еліт, демократична участь громадян уполітиці, а також зумовленість сприятливими політикокультурними орієнтаціями [21, с. 39].

Г.В. Музиченко робить важливий висновок про те, що місцева демократія визначає демократичні процеси на місцях, де поширена децентралізація державної влади, існують інститути місцевого самоврядування і громадянського суспільства, демократія виходить із народу, здійснюється народом та в інтересах народу [25, с. 321].

С.П. Була зазначає, що локальну демократію потрібно розуміти як тип самоврядування, яке є автономним, ефективним, відкритим та представницьким, функціонуючим у середовищі громадянського суспільства та гарантованих для громадян політичних прав [15, с. 17].

Є.0. Садикова у дисертаційному дослідженні «Інститут представництва на місцях в умовах трансформації системи місцевого самоврядування в Україні» наголошує на тому, що 
локальний чинник має істотне значення та виявляється в усіх моделях демократії, зокрема передбачає участь громадян у політичному житті, яка обумовлюється не тільки необхідністю захисту індивідуальних інтересів, але й розвитком загального усвідомлення громадської єдності, що й розглядається як передумова запровадження якісного політичного представництва на місцях [30, с. 53].

O.М. Лощихін та М.I. Мартинюк на основі аналізу зарубіжних та вітчизняних напрацювань визначають муніципальну (місцеву, локальну) демократію як місцевий рівень демократії, форму організації територіальної громади, у якій місцева громада є джерелом місцевої влади, зокрема громада формує органи місцевого самоврядування, має право та засоби керування й контролю за їхньою діяльністю, у тому числі за участі інститутів громадянського суспільства, і безпосередньо бере участь у прийнятті рішень, несе відповідальність за їх виконання [23, с. 8].

M.I. Цумарєв у дисертаційному дослідженні визначає локальну демократію як гарантований державою спосіб організації влади на локальному рівні (в межах місцевого самоврядування), що грунтується на самоорганізації політичної участі громадян (членів територіальної громади або іiі частини) у вирішенні питань місцевого значення, за допомогою унормованих механізмів та інструментів локальної демократії [33, с. 41].

Отже, локальна демократія - це спосіб організації влади на місцях, який полягає в участі громадян у виробленні та прийнятті владних рішень через інститути локальної демократії.

Важливим аспектом для розуміння локальної демократії $\epsilon$ визначення специфічних ознак, які властиві лише їй як інституційній формі організації політичного життя в громаді.

Міжнародний інститут демократії та сприяння виборам (International IDEA) визначив три фундаментальні основи локальної демократії:

- громадянство, рівні права і справедливість - включаючи громадянство на місцевому рівні, особисті, політичні права, економічні, соціальні і культурні права, верховенство закону та доступ до правосуддя;

- представницькі та підзвітні інститути й процеси - вибори та механізми прямої демократії на місцевому рівні, місцеві органи влади, політичні партії та інші інститути громадянського суспільства; 
- громадянська ініціатива і участь - активне залучення громадян і засобів масової інформації [38].

М.С. Бондар визначає шість ознак, які притаманні локальній демократії як політико-правовому явищу. По-перше, вона здійснюється в особливій сфері суспільних відносин, яку формують питання місцевого значення; по-друге, вона реалізується на нижньому територіальному рівні організації публічної влади; потретє, має своїми просторовими межами території муніципальних утворень; по-четверте, грунтуючись на принципах самоврядування, вона передбачає максимальне зближення керуючого і керованого суб'єктів, органів муніципальної влади і місцевої громади i, відповідно, безпосередньої і представницької демократії (проте без їх ототожнення); по-п'яте, вона організаційно відособлена від демократичних інститутів державної влади; по-шосте, муніципальна демократія не обмежується відносинами на державному рівні, але включає також інститути громадського, не публічно-владного характеру (наприклад, територіальне громадське самоврядування, опитування громадян, збори (конференції) [14, с. 19-20].

С.В. Крамаренко до ознак місцевої демократії відносить: з'єднання суб'єкта і об'єкту управлінської діяльності в місцевому самоврядуванні; максимально демократичні способи формування та склад механізму муніципального управління; врахування національних, історичних, культурних і інших місцевих особливостей при здійсненні місцевого самоврядування; забезпечення балансу державних і місцевих інтересів за допомогою ефективної взаємодії органів місцевого самоврядування та органів державної влади як демократичних органів народного представництва; можливість здійснення ефективного контролю з боку населення за діяльністю місцевих органів влади при одночасній відкритості цих органів [19, с. 33].

Учені М. Лендьєл та М. Токар серед ознак місцевої демократії визначають:

- приналежність до спільноти. Таким чином відбувається активізація участі жителів у ній;

- деліберація - для демократичного процесу важливим $\epsilon$ ефективний діалог між різними групами інтересу;

- політична освіта, яка необхідна для «усвідомленої» партисипації громадян та знання про політику на рівні з місцевою елітою, аби бути в однакових умовах в освітньому рівні; 
- контроль за діями уряду громадянами, адже висококваліфіковане та високоякісне виконання доброго врядування та соціального добробуту [22, с. 206].

Основними концептуальними характеристиками локальної демократії, на думку, С. Були є: організація життя територіальної громади на принципах рівності, участі, публічного діалогу; залучення громадян до ведення справ громади, поширення практик місцевих ініціатив, референдумів; самоорганізація населення [15, с. 18].

Підводячи підсумки, зазначимо, що локальній демократії притаманні такі особливості:

1) сприяє активному залученню місцевих жителів до вирішення питань через різні інститути локальної демократії;

2) виявляється у взаємодії органів місцевого самоврядування та жителів, що грунтується на взаємовідповідальності та взаємопідтримці;

3) дозволяє виявляти потреби міського населення та оперативно вирішувати місцеві проблеми;

4) передбачає поінформованість громадян про місцеву політикує та порядок ії̈ впровадження.

Також можна зробити висновок про те, що метою локальної демократії є розвиток народовладдя, широке залучення місцевих жителів до участі та вирішенні питань місцевого значення. Тому ефективна локальна демократія $\epsilon$ необхідною умовою для забезпечення стійкого й справедливого економічного і соціального розвитку, просування належного управління і заохочення демократичних цінностей.

\section{2. Правове регулювання локальної демократії}

Міжнародне право здійснює значний вплив на формування правової бази місцевого самоврядування і, відповідно, локальної демократії. Міжнародні акти розроблені 3 урахуванням узагальнення багаторічної позитивної практики правового регулювання та функціонування місцевого самоврядування взагалі та локальної демократії, зокрема у багатьох країнах світу.

На даному етапі численні міжнародно-правові та регіональні акти здійснюють значний вплив на створення єдиних стандартів місцевого самоврядування сучасних демократичних держав. Розроблення спільних принципів, на яких грунтується місцеве самоврядування та локальна демократія, $\epsilon$ важливим напрямком для формування єдиних стандартів. 
Слід зазначити, що європейська практика щодо імплементації норм міжнародних договорів увнутрішнє законодавство держав $\epsilon$ досить однорідною й закономірною та базується на превалюванні міжнародних актів над актами внутрішнього законодавства. Такий підхід сприяє укріпленню політичних, економічних, соціальних та культурних зв'язків європейського простору, поглибленню процесів глобалізації, забезпечення рівного обсягу громадянських та політичних прав людини тощо.

Відповідно до положень Конституції України чинні міжнародні договори, згода на обов'язковість яких надана Верховною Радою України, є частиною національного законодавства України. При цьому якщо міжнародним договором, ратифікованим нашою державою, встановлені інші правила, ніж передбачені законом, то застосовуються правила міжнародного договору [1].

Виходячи з даної конституційної норми, важливим $\epsilon$ висновок про провідне місце міжнародних договорів в системі джерел права України та про прагнення підтримати міжнародні стандарти в різних сферах життя суспільства, впроваджуючи їх на національному рівні.

Першим міжнародним документом, який визначив міжнародні стандарти у сфері співробітництва місцевої влади та має вихід на вирішення локальних питань розвитку територій, вважається Європейська рамкова конвенція про транскордонне співробітництво між територіальними общинами або властями, 1980. Відповідно до даного акта кожна Договірна Сторона зобов'язується підтримувати та заохочувати транскордонне співробітництво між територіальними общинами або властями, які знаходяться під іï юрисдикцією, та територіальними общинами або властями, які знаходяться під юрисдикцією інших Договірних Сторін (ст. 1).

Стаття 2 Конвенції розкриває термін «транскордонне співробітництво», який означає будь-які спільні дії, спрямовані на посилення та поглиблення добросусідських відносин між територіальними общинами або властями, які знаходяться під юрисдикцією двох або декількох Договірних Сторін, та на укладання 3 цією метою будь-яких необхідних угод або досягнення домовленостей. Транскордонне співробітництво здійснюється в межах компетенції територіальних общин або властей, визначеної внутрішнім законодавством (ст. 2). 
Наступні положення акта визначають власне суб'єктів співробітництва - територіальні власті та общини, засоби реалізації домовленостей і угод, їх типологію. У додатку визначені типові міждержавні угоди про співпрацю на місцевому та регіональному рівнях, а також рамкові угоди, договори та статути, які можуть слугувати основою для даного виду співробітництва між територіальними общинами або властями [3].

Україна приєдналася до цього документу у 1993 р. та, як зазначає O.B. Мошак, ця подія стала не лише фактом визнання потенційних можливостей України у сфері транскордонного співробітництва як європейської держави, що обрала демократичні орієнтири розвитку, і вираженням бажання країни брати участь уєвропейських інтеграційних процесах, що стрімко набирали силу і трансформувалися у домінантну тенденцію регіональної i глобальної міжнародної політики, але і своєрідним першим запрошенням до родини європейських народів [24, с. 72-73].

Транскордонне співробітництво в рамках єврорегіонів здійснюється в Україні з 1993 року. На території України утворено дев'ять єврорегіонів: Буг, Верхній Прут, Дністер, Дніпро, Карпатський, Нижній Дунай, Слобожанщина, Донбас та Ярославна. При цьому п'ять єврорегіонів утворено 3 державами - членами Європейського Союзу (Республіка Польща, Словацька Республіка, Румунія, Угорщина). Транскордонне співробітництво здійснюється, зокрема, на рівні територіальних громад, їх представницьких органів та сприяє соціальній та економічній конвергенції прикордонних регіонів та створенню нових можливостей для розвитку економічних, соціальних, науково-технічних, екологічних, культурних та інших відносин, обміну досвідом.

Визначальним $є$ прийняття у 2004 році Закону України «Про транскордонне співробітництво», який врегульовує правові, економічні та організаційні засади транскордонного співробітництва [9].

Протягом 2016-2020 років забезпечувалося виконання Державної програми розвитку транскордонного співробітництва на 2016-2020 роки, затвердженої постановою Кабінету Міністрів України від 23 серпня 2016 р. № 554, шляхом здійснення заходів та реалізації проектів транскордонного співробітництва (зокрема, в рамках програм прикордонного співробітництва Європейського інструменту сусідства та ініціативи ЄС «Східне партнерство»), спрямованих на розвиток транскордонного співробітництва та формування позитивного інвестиційного іміджу України. 
14 квітня 2021 року Кабінет Міністрів України ухвалив постанову «Про затвердження Державної програми розвитку транскордонного співробітництва на 2021-2027 роки», яка була розроблена Мінрегіоном на виконання Закону України «Про транскордонне співробітництво».

У документі визначено пріоритетні напрями розвитку транскордонного співробітництва на період до 2027 року, серед яких:

- реалізація в Україні Стратегії Європейського Союзу для Дунайського регіону та Дунайської транснаціональної програми;

- реалізація проектів (програм), що фінансуються за рахунок міжнародної технічної допомоги, а також програм прикордонного співробітництва у рамках Європейського територіального співробітництва на 2021-2027 pp. у рамках фінансового інструменту «Сусідство, розвиток і міжнародне співробітництво» (NDICI);

- розвиток прикордонної інфраструктури гірських територій Карпат;

- розвиток інституційної спроможності суб’єктів та учасників транскордонного співробітництва (асоціацій органів місцевого самоврядування, громадських організацій, європейських об'єднань територіального співробітництва та інших форм транскордонного співробітництва) [12].

На шляху вдалої реалізації даної Програми наразі існують численні перепони. Зокрема, залишаються нерозв'язаними проблеми розвитку прикордонної транспортної інфраструктури, охорони і відновлення екосистем регіонів, низької інституційної спроможності суб'єктів та учасників транскордонного співробітництва. Найсерйознішим викликом та перепоною для транскордонного співробітництва України на ії східному та південному державному кордоні є збройна агресія Російської Федерації проти України та спроба анексії Російською Федерацією Автономної Республіки Крим та м. Севастополя, що унеможливлює реалізацію транскордонного співробітництва України із цією державою [12].

Важливим актом, який гарантує право територіальних громад на самоврядування, $\epsilon$ Європейська Хартія місцевого самоврядування від 15 жовтня 1985 року (обов'язкова для України відповідно до Закону України «Про ратифікацію Європейської хартії місцевого самоврядування» від 15 липня 1997 року) [7]. В основу Хартії покладено державну теорію місцевого самоврядування. При приєднанні до Хартії кожна з держав, дотримуючись загально- 
європейських стандартів, має виробити свою національну модель самоврядування, виходячи із власних потреб і традицій. Даний акт не містить чіткої вказівки на значення чи інструменти локальної демократії, але $\epsilon$ актом, що закладає основи системи місцевого самоврядування, яке нерозривно пов'язано 3 локальною демократією та містить чітке положення про те, що ефективне самоврядування на місцях $\epsilon$ істотним елементом демократії.

Більшість положень Хартії сприйнято національним українським законодавством та розвинуто у його нормах, поряд із цим потребують подальшого вдосконалення механізми забезпечення фінансової самостійності органів місцевого самоврядування України.

Наступним документом, зміст якого значною мірою збігається 3 положеннями Європейської хартії, $\epsilon$ Всесвітня Декларація місцевого самоврядування, яка була прийнята XXVII Конгресом Міжнародної Спілки місцевої влади 26 вересня 1985 р. у м. Ріо-деЖанейро (Бразилія) [17]. Декларація не є документом, обов'язковим для виконання Україною, але становить значний інтерес, адже в ній знайшла свій відбиток і закріплення позиція широких кіл світової громадськості, активістів і спеціалістів муніципального руху з питань становлення і функціонування локальної демократії.

Наступним документом, який визначає важливість використання інструментів локальної демократії, $\epsilon$ Конвенція про участь іноземців у громадському житті на місцевому рівні, яка була прийнята у 5 лютого 1992 р. Даний акт закріплює можливість надання іноземцям низки політичних прав, щоправда, з деякими обмеженнями і лише на місцевому рівні.

Відмітимо, що в Конвенції використовується термін «постійні мешканці-іноземці», під яким розуміються особи, що не $\epsilon$ громадянами держави, на території якої вони мешкають на законних підставах [35].

Дана Конвенція визначає, що Сторони зобов'язуються гарантувати іноземцям, які живуть на їх території, на тих же умовах, що і власним громадянам, так звані «класичні права», зокрема право на свободу виявлення поглядів; право на свободу мирних зборів i свободу асоціації 3 іншими, включаючи право створювати профспілки і вступати до них для захисту своїх інтересів.

Вважаємо, що акт містить важливе положення, яке стосується надання кожному постійному мешканцю-іноземцю право голосувати та висувати свою кандидатуру на виборах до органів місцевого самоврядування, якщо він задовольняє тим правовим вимогам, які пред'являються громадянам i, крім того, на 
законних підставах постійно мешкає у відповідній державі упродовж п'яти років, що передують виборам.

Зазначимо, що питання про наділення іноземців виборчими правами не $\epsilon$ новим та задеклароване в конституціях багатьох європейських держав. Наприклад, право голосу на місцевих виборах за іноземцями було закріплено в Ірландії 1963 року, Швеції - 1976-го, Данії - 1981-го, Норвегії - 1982-го, у Нідерландах - 1985 року. Право голосу на місцевих виборах іноземці мають i у п'яти швейцарських кантонах (Neuchâtel, Юpa, Vaud в 2003, Фрібур в 2004, Женева в 2005), ще три кантони - Аппенцель Ausserrhoden (1995), Graubünden (2003) і Базель-Stadt (2005) надають кожному муніципалітету повноваження вибрати чи надавати такі права іноземцям [28, с. 374].

Що стосується умов реалізації пасивного виборчого права на місцевих виборах, то законодавством всіх країн $Є C$ встановлено дві основні умови реалізації особою права бути обраною:

1) наявність активного виборчого права на загальнодержавних або місцевих (для іноземних громадян) виборах;

2) включення до списку виборців на території відповідного муніципалітету.

У зв'язку з тим, що включення до списку виборців на території муніципалітету в більшості країн ЄС здійснюється за місцем проживання виборця, то кандидатом на місцевих виборах може бути зареєстрована лише особа, яка проживає в межах відповідного муніципалітету.

Отже, для практики країн-членів ЄС характерним $є$ надання пасивного виборчого права на місцевих виборах громадянам інших держав, у тому числі й тих, які не $\epsilon$ членами $€$. Можливість реалізації пасивного виборчого права на місцевих виборах поставлена у залежність від місця проживання особи - особа може балотуватись на виборах лише до того органу місцевого самоврядування, до якого вона має право обирати [29].

Зауважимо, що українське законодавство в питанні активного та пасивного виборчого права іноземців займає протилежну позицію. Відповідно до статті 70 Конституції України право голосу на виборах і референдумах мають громадяни України, які досягли на день їх проведення вісімнадцяти років [1]. Тобто імперативна норма Основного Закону чітко визначає осіб, які мають активне виборче право, при цьому виключає іноземців з їх числа як на національному, так і на місцевому рівні зокрема. 
Вважаємо, що надання виборчих прав іноземцям на місцевому рівні $є$ логічним та відповідає основним демократичним засадам. Іноземці, які проживають на території України на законних підставах, повинні мати право на вирішення питань місцевого значення, адже вони безпосередньо їх стосуються. А встановлення цензу громадянства позбавляє їх можливості брати участь увирішенні питань місцевого значення, що не узгоджується із сутністю місцевого самоврядування зокрема. Адже стаття 2 Закону України «Про місцеве самоврядування в Україні» визначає, що місцеве самоврядування в Україні - це гарантоване державою право та реальна здатність територіальної громади - жителів села чи добровільного об'єднання у сільську громаду жителів кількох сіл, селища, міста - самостійно або під відповідальність органів та посадових осіб місцевого самоврядування вирішувати питання місцевого значення в межах Конституції і законів України [8].

Отже, в законодавчому визначенні застосовується термін «жителі», а тому під дану категорію можуть підпадати не тільки громадяни, а й іноземці, особи без громадянства тощо. Тому приєднуємося до думки Л.А. Чернявського, який зазначає, що через невідповідність категорій виникає парадоксальна ситуація, коли іноземці та особи без громадянства визнаються членами відповідної територіальної громади, але не наділяються правами ії членів [32, с. 26].

Вважаємо, що надання іноземцям виборчих права на місцевому рівні $\epsilon$ необхідною передумовою для впровадження в Україні європейських стандартів локальної демократії. Звісно, що надання такого спектру прав потребує детальної та виваженої регламентації.

Наступний акт, який не можна обійти увагою у ракурсі даної теми, - це Європейська хартія про участь молоді в муніципальному і регіональному житті 1992 р., переглянута у 2003 р. Хартія визначає, що активна участь молодих людей в ухваленні рішень і діяльності на місцевому і регіональному рівнях має важливе значення, для побудови більш демократичного, солідарного та процвітаючого суспільства [4].

У Хартії представлені конкретні ідеї та інструменти, що можуть бути використані у ситуації на місцях тими, хто залучений до процесів сприяння участі молоді - молодими людьми, молодіжними організаціями, місцевими органами влади тощо. Тим не менш, Хартія не пропонує готового шаблону для щоденного застосування, адже потреби молоді, обставини різняться у всій Європі. 
Отже, Хартія $\epsilon$ керівництвом із підтримки молоді в частині ії̈участі в ухваленні рішень, які безпосередньо зачіпають її інтереси. Вона закликає молодь проявляти більше активності в реалізації соціальних змін, що відбуваються на муніципальному та регіональних рівнях.

Наступними важливими актами $є$ «євопейська хартія міст» (1992); «Європейська хартія міст II (Маніфест нової урбаністики)» (2008) [5;6].

Європейська хартія міст, прийнята 18 березня 1992 р. у вигляді рекомендації, визначає права громадян, які проживають в європейських містах. Вона регулює основні аспекти міського управління, зокрема питання щодо умов проживання, міського транспорту, архітектури, культури тощо.

Важливим положенням Європейської хартії міст є п.3.3., який розкриває сутність та значення місцевої демократії. Зокрема, в ньому говориться, що не завжди було так, щоб у місцевих жителів була достатня можливість висувати свої вимоги через наявні установи і брати участь в демократичному процесі міського розвитку. Цей недолік особливо серйозний тому, що спосіб функціонування міст обумовлює ефективність захисту демократії і прав. Якщо вони функціонують добре, вони $\epsilon$ гарантією прав людини; якщо вони функціонують погано, то ці права знаходяться в небезпеці. Основою міського розвитку має бути пряма участь громадян у рамках місцевого органу влади, який сам повинен мати найбільші автономію і фінансову незалежність [5]. Отже, Хартія комплексно закріплює принципи місцевої демократії, сфери і форми ії реалізації.

«Європейська хартія міст II (Маніфест нової урбаністики)» прийнята 29 травня 2008 року. Пункт 29 даного акту визначає, що для реалізації сучасної місцевої демократії передбачено створення рад виборних осіб на різних рівнях для ухвалення рішень в містах, які б при цьому пропонували населенню інформаційні структури, проводили публічні обговорення i встановлювали співпрацю у рамках міського планування [6].

Для забезпечення максимальної ефективності різних заходів Європейська хартія міст II закликає міста повною мірою використовувати нові інформаційні технології для поліпшення консультацій з громадянами щодо містобудівних проектів. Також наголошено на важливості створення системи потужної електронної демократії, яка допоможе створити новий потенціал демократичної мобілізації. 
Наступним актом, який містить положення про важливість розвитку та утвердження локальної демократії, $\epsilon$ Додатковий протокол до Європейської хартії місцевого самоврядування про право участі у справах органу місцевого самоврядування, прийнятий 16 листопада 2009 року та ратифікований Україною 2 вересня 2014 року [2].

Відповідно до Статті 1 даного акта Держави-Сторони в рамках своєї юрисдикції повинні забезпечувати кожному право участі у справах місцевого органу влади. Право участі у справах місцевого органу влади означає право вживати рішучих заходів для визначення або впливу на здійснення повноважень та обов'язків місцевого органу влади.

Для реалізації права участі у справах місцевого органу сторони повинні вживати всіх таких заходів, які $\epsilon$ необхідними для здійснення права участі у справах місцевого органу влади.

Відповідно до статті 2 Додаткового протоколу такі заходи повинні включати:

1) надання місцевим органам влади повноважень надавати правоучасті, викладене в цьому Протоколі, сприяти його здійсненню;

2) забезпечення створення: процедур залучення людей, які можуть уключати консультаційні процеси, місцеві референдуми й звернення та у випадках, коли на території органу місцевого самоврядування $є$ багато жителів та (або) коли орган місцевого самоврядування охоплює великий географічний регіон, заходи із залучення людей на рівні, найближчому до них; процедур доступу згідно 3 конституційним порядком та міжнародноправовими зобов'язаннями Сторони до офіційних документів, які $\epsilon$ в розпорядженні місцевих органів влади; заходів для задоволення потреб категорій осіб, які натрапляють на конкретні перешкоди в участі, а також механізмів і процедур розгляду скарг і пропозицій стосовно функціонування місцевих органів влади й місцевих комунальних служб та реагування на такі скарги й пропозиції;

3) сприяння використанню інформаційно-комунікаційних технологій для розвитку та здійснення права участі, викладеного в цьому Протоколі [2].

Даний акт визначає важливість та необхідність впровадження демократичного принципу щодо права участі кожного у веденні суспільних справ, зокрема в рамках місцевого самоврядування. 
Слід зазначити, що у 1994 р. Рада Європи заснувала Конгрес місцевої і регіональної влади Ради Європи в якості консультативного органу, який $€$ форумом для проведення зустрічей $\mathrm{i}$ дискусій представників обраних органів місцевої і регіональної влади, а також для обміну думками відносно місцевої i регіональної політики країн-учасників.

Важливою подією для України стало підписання Президентом України у березні 2021 року Указу № 89/2021 «Про затвердження Положення про Конгрес місцевих та регіональних влад при Президентові України» [10].

Згідно 3 документом, Конгрес $\epsilon$ консультативно-дорадчим органом, серед основних завдань якого, зокрема, сприяння ефективному завершенню реформи місцевого самоврядування та налагодженню ефективної взаємодії державних органів, а також моніторинг суспільно-політичних і соціально-економічних процесів, що відбуваються в державі на регіональному та місцевому рівнях.

Конгрес братиме участь у виробленні державної регіональної політики. Крім того, він має вивчати та узагальнювати міжнародний досвід у сфері територіального розвитку з урахуванням стандартів Європейської хартії місцевого самоврядування, а також організовувати роботу щодо формування складу делегації України в Конгресі місцевих і регіональних влад Ради Європи [9].

Відповідно до Резолюції 91 (2000р.) Конгресу місцевої і регіональної влади Ради Європи втілення в життя політики держави, грунтованої на принципах демократії, будується на повсюдній повазі прав і свобод людини і громадянина, активній участі останніх в політичному житті держави i місцевого співтовариства за допомогою розділення загальних демократичних ідеалів. Такі громадяни постійно цікавляться державною i громадською обстановкою, а також цілком ясно усвідомлюють відповідальність за свої дії, у тому числі і бездіяльності. Залучення громадян до муніципальної демократії $\epsilon$ життєвим джерелом енергії муніципалітетів.

Відповідно до Резолюції муніципальна демократія $\epsilon$ універсальним інститутом сучасного громадянського суспільства i правової держави. Жива демократія на місцевому рівні $\epsilon$ запорукою життєздатної демократії на рівні державному [27].

У рамках виконання своїх статутних функцій Конгрес місцевих і регіональних влад Ради Європи здійснює моніторинг виконання державами-членами РЄ Європейської хартії місцевого 
самоврядування, а також спостереження за місцевими й регіональними виборами у цих країнах. Ці два напрями $\epsilon$ основними у співпраці Конгресу місцевих і регіональних влад з Україною та обумовлюють зміст й тональність розгляду пов'язаних з Україною питань у рамках цього консультативного органу Ради Європи.

У ході останнього моніторингового візиту делегації Конгресу місцевих і регіональних влад в Україну 4-6 березня 2020 р. спецдоповідачі щодо України - представниці Норвегії та Австрії підготували звіт про стан місцевої та регіональної демократії в Україні. 17 вересня 2020 р. Моніторинговий комітет Конгресу місцевих і регіональних влад ухвалив цей документ та проєкт відповідної рекомендації Уряду України. Обидва документи обговорюватимуться на одній із наступних сесій Конгресу місцевих і регіональних влад (восени 2021 р. чи навесні 2022 р.).

Ще одним документом, який не можна оминути увагою, $є$ Стратегія інновацій та доброго врядування на місцевому рівні 2008 р., яка ухвалена Комітетом Міністрів Ради Європи. Даний Документ має програмний характер та визначає принципів доброго демократичного врядування на місцевому рівні. До таких принципів належать: чесне проведення виборів, представництво та участь; зворотний зв'язок, чутливість; ефективність та результативність; відкритість і прозорість; верховенство права; етична поведінка; компетентність і спроможність; інноваційність та відкритість до змін; раціональне управління фінансами; права людини, культурне різноманіття та соціальна згуртованість; підзвітність, для забезпечення того, щоб місцеві (виборні) представники та службовці брали відповідальність та були відповідальними за свою діяльність [24, с. 79].

Принципи окреслюють оновлену модель місцевого управління, яка спрямована на підвищення ефективності взаємодії місцевих жителів на основі відкритості, довіри та прозорості, враховує виклики сучасності, збільшення демократичних вимог людей i дозволяє реалізовувати місцеву політику у найбільш прийнятний для людей та усіх заінтересованих сторін спосіб.

Отже, на сучасному етапі ряд міжнародних та регіональних документів з питань локальної демократії отримали ратифікацію в Україні. Це $є$ важливим кроком для впровадження стандартів локальної демократії, які випробувані багаторічною міжнародною демократичною практикою та мають практичне значення для розбудови сучасної системи місцевого самоврядування. 
Слід зазначити, що в останні роки в Україні значна увага приділяється питанням локальної демократії. Зокрема, у 2007 році Президентом України був прийнятий Указ «Про Європейський тиждень місцевої демократії» № 922/2007 від 27.09.2007 року, яким започатковано офіційний старт Європейського тижня місцевої демократії, який проводиться щорічно [11]. Також все активніше застосовуються інструменти локальної демократії та інструменти участі - методи прямого впливу на діяльність влади та процес прийняття рішень.

Аналізуючи нормативно-правове регулювання локальної демократії в Україні, зауважимо, що Конституція та Закони України закріплюють достатньо широкий перелік можливих форм локальної демократії, до яких, зокрема, належать: створення i діяльність об'єднань громадян та органів самоорганізації населення, місцеві ініціативи, загальні збори, місцеві референдуми, громадські слухання, громадський контроль та інші. Але якісне застосування даних інструментів потребує детальної регламентації, зокрема на локальному рівні.

Оскільки внаслідок нестачі необхідних локальних нормативних актів, які покликані конкретизувати законодавчі положення щодо порядку використання інструментів локальної демократії, значно стримується розвиток та активне використання всіх наявних засобів локальної демократії.

Ще однією важливою проблемою $\epsilon$ низький рівень поінформованості громадян про власні можливості брати участь у вирішенні питань місцевого значення. Дана ситуацію в першу чергу зумовлена традиційно низькою активністю громадян, їхнім небажанням займати активну громадську позицію.

Розв'язання нагальних проблем, які виникають на шляху розвитку локальної демократії, потребує комплексного підходу, який повинен враховувати світовий досвід та вітчизняні особливості. Адже ефективне функціонування локальної демократії $\epsilon$ запорукою реалізації прав громадян, сприяє широкому залученню місцевих жителів до вирішення питань та проблем, які виникають на місцях, створює належні та гідні умови проживання, відіграє важливе значення для формування та підвищення правової свідомості громадян. 


\section{Висновки}

Дієва локальна демократія $\epsilon$ основою ефективної та міцної національної демократії. Саме місцевий рівень $\epsilon$ визначальним, оскільки саме тут громадяни вперше знайомляться з політичною системою, частиною якої вони є; це їх первинна основа для політичної участі та представництва.

Значення локальної демократії полягає в можливості ширшої участі населення у вирішенні питань місцевого значення, що зумовлює підвищення рівня правової культури, формує соціальні цінності населення, з одного боку, та впливає на поліпшення надання послуг та роботу органів місцевої влади за рахунок підвищення підзвітності громадськості, з іншого. Саме локальна демократія відбиває потреби та інтереси місцевих жителів, сприяє ефективному та оперативному вирішенню проблем та потреб, які можуть виникати на місцях; поліпшує взаємодію населення та якість надання послуг.

Належне функціонування демократичних інститутів та процесів на місцевому рівні $\epsilon$ визначальним та важливим фактором, оскільки активна громадянська позиція на місцевому рівні закладає фундамент для сильної на стабільної демократії на національному рівні. Адже політика на національному рівні визначає практику та методи роботи на місцевому рівні, у той час як досвід на місцевому рівні $\epsilon$ основою для національної політики та реформ.

Належну місцеву демократію найкраще підтримувати та розвивати у взаємодії між жителями, місцевою владою та державою. Держава повинна створювати якісну та дієву нормативно-правову базу для ефективної локальної демократії. Значення діяльності місцевої влади полягає в першу чергу у сприянні широкій участі громадян у вирішенні питань та проблем місцевого значення; по-друге, важливо забезпечити можливість мешканцям висловити свою думку щодо місцевої політики та створити доступні умови взаємодії та постійного діалогу. Мешканці, у свою чергу, повинні проявляти зацікавленість, використовувати різні можливості для висловлення своїх поглядів на те, як здійснюється управління на місцях. Адже як виборці, які обрали своїх представників, мешканці також несуть відповідальність за діяльність місцевої влади. 


\section{Список використаних джерел:}

1. Конституція України : Закон України від 28.06.1996 № 254к/96-BP. URL : https://zakon.rada.gov.ua (дата звернення: 01.06.2021).

2. Додатковий протокол до Європейської хартії місцевого самоврядування про право участі у справах органу місцевого самоврядування : Закон № 1664-VII від 02 вересня 2014 року. URL : https://zakon.rada.gov.ua/laws/show/994_b49\#n2 (дата звернення: 01.07.2021).

3. Європейська Рамкова Конвенція про транскордонне співробітництво між територіальними общинами або властями. Мадрид, 21 травня 1980 p. URL : http:zakon.rada.gov.ua/cgibin/laws/main.cgi (дата звернення: 06.07.2021).

4. Європейська хартія участі молоді в громадському житті на місцевому i регіональному рівні. URL : http://humanrightsinukraine.org.ua/wpcontent/uploads/2015/10/ eu_charter_ukr.pdf (дата звернення: 04.07.2021).

5. Європейська хартія міст, 17 травня 1992 p. URL : http://uristinfo.net/2010-12-18-14-34-28/42-pdbilenchuk-mistsevesamovrjaduvannja-vukrayini/743-evropejskaja-hartija-gorodov.html (дата звернення: 11.07.2021).

6. Європейська хартія міст II (маніфест нової урбаністики), 29 травня 2008 p. URL : http://www.slg-coe.org.ua/wp-content/ uploads/2015/05/Principle-9.- European-chart.pdf (дата звернення: 11.07.2021).

7. Європейська хартія місцевого самоврядування: Рада Європи; Хартія, Міжнародний документ від 15.10.1985. Офіційний вісник. 2015 р. № 24, / № 39, 2013, ст. 1418/, стор. 450, стаття 718.

8. Про місцеве самоврядування в Україні : Закон України від 21 травня 1997 р., № 280/97-ВР. Відомості Верховної Ради України. 1997. № 24.

9. Про транскордонне співробітництво : Закон України 24 червня 2004 року. № 1861-IV. URL : http://zakon.rada.gov.ua/ cgi-bin/laws/main.cgi (дата звернення: 03.07.2021).

10. Положення про Конгрес місцевих та регіональних влад при Президентові України : Указ Президента України від 4 березня 2021 року № 89/2021. URL : https://www.president.gov.ua/ documents/892021-37105 (дата звернення: 08.07.2021).

11. Про Європейський тиждень місцевої демократії : Указ Президента України від 27.09.2007 року № 922/2007. 
URL : https://zakon.rada.gov.ua/laws/show/922/2007\#Text (дата звернення: 06.06.2021).

12. Про затвердження Державної програми розвитку транскордонного співробітництва на 2021-2027 роки : Постанова Кабінету Міністрів України від 14 квітня 2021 р. № 408. URL : https://zakon.rada.gov.ua/laws/show/408-2021-\%D0\%BF\#Text. (дата звернення: 01.07.2021).

13. Батанов О. Муніципальна влада у системі сучасного муніципалізму: концептуальні проблеми теорії. Юридичний вісник. 2010. № 3. С. 16-22.

14. Бондарь Н.С. Местное самоуправление и конституционное правосудие: конституционализация муниципальной демократии в России. Москва : Норма, 2009. 592 с.

15. Була С. Теоретико-методологічний аналіз локальної демократії як умови та інструменту становлення консолідованої демократії в перехідних суспільствах (на прикладі України) : автореф. дис. ... канд. політ. наук : 23.00.01. Львів, 2012. 19 с.

16. Бурін О.М. Проблеми впровадження концепції локальної демократії в Україні. Державне управління: удосконалення та розвиток. 2014. № 9. URL : http://www.dy.nayka.com.ua/ ?op=1\&z=752 (дата звернення: 25.06.2021).

17. Всесвітня декларація місцевого самоврядування. Місцеве та регіональне самоврядування Украӥни. 1994. Вип. 1/2 (6/7). С. 65-69.

18. Демократия и местное самоуправление. Реферат на книгу: Hill D.M. Democratic theory and local government. Москва, 1994.

19. Крамаренко С.В. Развитие институтов непосредственной демократии в местном самоуправлении: теоретико-правовые и прикладные аспекты: дис. ... канд. юр. наук : 12.00.02. Воронеж, 2013. 234 c.

20. Лермонтов Ю.М. Теоретико-правовые основания муниципального народовластия. Социология власти. 2009. № 2. С. 210-214.

21. Лендьєл М. Місцева демократія у країнах Центральної і Східної Європи: монографія. Ужгород : Мистецька лінія, 2011. 688 с.

22. Лендьєл М. Регіональні та місцеві аспекти політики. Науковий вісник Ужгород. ун-ту. 2010. Вип. 15. С. 204-210.

23. Лощихін O.М. Теоритичні підходи до визначення поняття та особливостей муніципальної демократії. Право.иа. 2017. № 3. C. 5-9. 
24. Мошак О.В. Міжнародні стандарти локальної демократії і транскордонне співробітництво: шляхи розбудови. Lex Portus. 2019. № 3. С. 69-84.

25. Музиченко Г.В. Основні компоненти місцевої демократії в сучасній Україні. Труды Одесского политехнического университета. 2002. Вып. 2(18). С. 320-323.

26. Новоселов А.А. Применение концепции «местной демократии» в современном процессе государственного строительства Европейских стран : дис. ... канд. полит. наук : 23.00.02. Новгород, 2006. 168 с.

27. Об обязанностях граждан и участии в общественной жизни : Резолюция 91 Конгресса местных и региональных властей Совета Европы. 2000. URL : https://rm.coe.int/-91-2000-1/1680719055 (дата звернення: 30.06.2021).

28. Право Европейского Союза / под общ. ред С.Ю. Кашкина. Москва : Юристъ, 2002. 925 с.

29. Право обирати і бути обраним в країнах ЄC: суб'єкти, умови і механізми реалізації. URL : https://parlament.org.ua/ docs/files/8/1150892449_ans.pdf (дата звернення: 10.07.2021).

30. Садикова Є.О. Інститут представництва на місцях в умовах трансформації системи місцевого самоврядування в Україні : дис. ... канд. політ. наук : 23.00.02. Одеса, 2016. 206 с.

31. Тюлегенов А.Э. Муниципальная демократия как механизм реализации местного самоуправления. Административное $u$ муниципальное право. 2014. С. 689-695.

32. Чернявський А.Л. Проблеми реалізації виборчих прав іноземців та осіб без громадянства в контексті євроінтеграції України. Вісник Університету банківської справи Національного банку України. 2014. № 3. С. 25-27.

33. Цумарєв M.I. Формування громадянської культури локальної демократії в сучасній Україні : дис. ... канд. політ. наук : 23.00.03. Київ, 2019. 245 с.

34. Burns D. Can Local Democracy Survive Governance? Urban Studies. 2000. Vol. 37. № 5/6. P. 963-973.

35. Convention on the Participation of Foreigners in Public Life at Local Level, 1992. URL : https://rm.coe.int/CoERMPublicCommon SearchServices/DisplayDCTMContent?documentId $=090000168007 \mathrm{bd}$ 26 (дата звернення: 11.07.2021).

36. Decentralization and Local Democracy in the World : First Global Report 2008 : United Cities and Local Governments, the World Bank. 2008. 350 p. 
37. Local democracy/ International Institute for Democracy and Electoral Assistance. URL : https://www.idea.int/publications/catalogue/ local-democracy (дата звернення: 19.06.2021).

38. Local democracy today and tomorrow - learning from good practice. URL : http://www.clgf.org.uk/default/assets/File/Publications/ reports/Local_Democracy_today_and_tomorrow-learning_from_good_ practice-IDEA-CLGF-CityInsight2014.pdf (дата звернення: 01.07.2021).

39. Soós G. Introduction. Faces of Local Democracy. Comparative Papers from Central and Eastern Europe. Budapest : OSILGPSRI, 2005. 307 p.

40. Stone C.N. Urban Regimes and the Capacity to Govern: A Political Economy Approach. Journal of Urban Affairs. 1993. Vol. 15. № 1. p. 1-28. 